\title{
Sea Voyages to Paracel Islands in the South China Sea Under Emperor Minh Mang (1833-1838), the analyses of historical data - description
}

\author{
Ha Minh Hong ${ }^{1}$, Le Thanh Hoa ${ }^{2}$, Dai-Long Ngo-Hoang ${ }^{3}$, Nguy Ngoc Thuy ${ }^{4}$, Huynh Tam Sang ${ }^{5}$, \\ Nguyen Thi Thu Thuy ${ }^{6}$ \\ 1,2,3,4,5,6 University of Social Sciences and Humanities, Vietnam National University - Ho Chi Minh City \\ (VNUHCM-USSH)
}

\begin{abstract}
The Official Documentation of the Nguyen dynasty is a type of administrative documentation of the House of Nguyen (1802-1945) on which reserved the king's handwritten feedback in red ink. The Official documentation about the implementation of Vietnam's sovereignty over Paracel Islands (Paracel) and Truong Sa (Spratly) archipelagos includes 19 documents, 12 of that (from document no. 5 to no. 16) reflect mission sea voyages of the fleet heading to Paracel Islands archipelagos from late March to late June, from 1833 to 1838. The following are the main features of these activities include: (i) in each sea voyage, they had different tasks such as measuring and mapping; bringing materials to build the temple...; (ii) The activities during this period under King Minh Menh clearly showed the strict management and the responsibility of the national leader to the national territory in general and islands in particular; (iii) the territory acquire the nationality in Paracel Islands from 1833 to 1838 , which was the continuity of a process established by the Nguyen Lords from hundreds of years ago.
\end{abstract}

Keywords: Paracel Islands archipelagos, the Nguyen dynasty, mission, voyages

The mission of the Nguyen Dynasty (Vietnam) to the two groups of Paracel Islands (Paracel) and Truong Sa (Spratly) archipelagos was carried out soon. This fact was recognized in the early 17th century and lasted until 1838 under the reign of Emperor Minh Mang. In 1816, Gia Long King officially possessed the Paracels, giving instructions to set up flags in the islands and take measurements of the sea routes (Keyuan, 2001). Jules Brevie, the French Resident Superior in Indochina, gave the order to establish an administrative body of the Paracels and place a stele, in which the following words were written: "Republic of France - Kingdom of Annam - Paracels Archipelago, 1816”[16]. In 1835, Minh Mang King gave instructions to build temples, place steles, drive in stakes and plant trees. The Paracel Islands Team and the Bac Hai Team were assigned to undertake the task of exploitation, patrol, tax collection, and national defense over the two archipelagoes. The two teams continued undertaking the task, until the French troops invaded Indochina. Since then, the administrative management of those islands was maintained by the Nguyen Dynasties in order to provide support for sea journeys as well as collect taxes from local fishing residents till 1847-1848 [17].

According to Vu Quang Viet (2020), a researcher, the historical documents on the Paracels possession show that "Vietnam proclaimed clearly and exercised its sovereignty over the Paracels for at least 70 years, from some time before the year of 1770 to the year of 1816, when Gia Long King officially proclaimed the sovereignty. It continued lasting till the time of Minh Mang Emperor, when it was clearly written in the official history (1837) Vietnam's possession of the Paracels written officially in history, therefore, lasted continually for at least 74 years (since 1774); i.e. from the time of the trip to the Paracels mentioned by Le Quy Don to the time, when Minh Mang Emperor gave instructions to draw the maps. The will and activities of Gia Long King and Minh Mang King for sovereignty affirmation were shown in official documents. Although each trip to the islands lasted at most 6 months, it happened continually year by year. It is really enough to demonstrate this"[18]. Thus, researching historical missions will give us a more general look in the context of ancient history

\section{METHODOLOGY}

This article is part of a project was funded by VNU-HCM under grant number B2017-18b-01 that I started in 2017 in HoChiMinh City, on "Document the specification of Vietnam's sovereignty over the two archipelagos: Paracel and Spratly". I use descriptive research with various methods, including general analytical methods, comparative data, historical critique and statistical data to serve this article.

\section{EXPERIMENTAL RESULTS} documentations

1. A summary about mission sea voyages heading to Paracel Islands archipelagos recorded in 
Paracel Islands (Hoang Sa) is a remote administrative area of the Nguyen Dynasty, therefore, the annual management is a routine (Ramsay, 2008). The statistics below from the collection of the Nguyen Dynasty's Official Documentation describes the work of recruiting forces to join the fleet:

\begin{tabular}{|c|c|}
\hline Sea voyages by the year & Recruitment and main tasks \\
\hline $\begin{array}{l}\text { The sea voyage in } 1833 \\
\text { Document 5: The Official document on } \\
\text { November 22nd in the fourteenth year of Minh } \\
\text { Menh reign (1833) } \\
\text { Origin: the Imperial Cabinet } \\
\text { Archive: National Archives Centre I. } \\
\text { Notation: Volume 49, page } 233-234\end{array}$ & $\begin{array}{l}\text { Imperial city: Captain Truong Phuc Si }(8,94) \text {, envoys. } \\
\text { Provinces: } 02 \text { marine guides were Vu Van Hung and Pham Van } \\
\text { Senh, } 18 \text { boatmen and sailors. }\end{array}$ \\
\hline $\begin{array}{l}\text { The sea voyage in } 1834 \\
\text { Document 6: The Official document on } \\
\text { April } 15^{\text {th }} \text { in the fifteenth year of Minh Menh } \\
\text { reign } \\
\text { Origin: Administration Commissioner and } \\
\text { Surveillance Commissioner of Quang Ngai } \\
\text { province } \\
\text { Archive: The National Boundary Commission }\end{array}$ & $\begin{array}{l}\text { Imperial city: Captain Truong Phuc Si [8,94], experienced } \\
\text { envoys, } 20 \text { marines ; manoeuvred and renovated } 3 \text { large ships. } \\
\text { Truong Phuc Si drew the map [5, file 4, 120] } \\
\text { Province: Marine guide Vu Van Hung, } 2 \text { licensed boatmen were } \\
\text { Dang Van Xien and Duong Van Dinh, } 09 \text { sailors (labour workers); } \\
\text { hired and upgraded } 3 \text { quick and light ships, packed with goods. } \\
\text { Each ship carried } 8 \text { people. }\end{array}$ \\
\hline $\begin{array}{l}\text { The sea voyage in } 1835 \\
\text { Document } 7 \text { : The Official document on } \\
\text { July } 17^{\text {th }} \text { in the sixteenth year of Minh Menh } \\
\text { reign }(1835)\end{array}$ & \\
\hline $\begin{array}{l}\text { Origin: the Imperial Cabinet } \\
\text { Archive: National Archives Center I. } \\
\text { Notation: Book No: } 54 \text {, page } 94 \\
\text { Document } 8 \text { : The Official document of } \\
\text { July } 17^{\text {th }} \text { in the sixteenth year of Minh Menh reign } \\
(1835)\end{array}$ & $\begin{array}{l}\text { Imperial city: Captain Pham Van Nguyen, } 03 \text { Imperial } \\
\text { guards were Tran Van Van, Nguyen Van Tien and Nguyen Van } \\
\text { Hoang ( drewthe map), navy soldiers (soldiers, labour soldiers...). } \\
\text { (Labour soldiers: erected temples, stone stelae and folding screens } \\
\text { [5, vol.4, } \\
\text { Province: Vu Van Hung and Pham Van Senh were guides, seamen } \\
\text { (labour workers) }\end{array}$ \\
\hline $\begin{array}{l}\text { Origin: Imperial Cabinet } \\
\text { Archive: National Archives Center I. } \\
\text { Notation : Book No : } 54 \text {, page } 94\end{array}$ & \\
\hline
\end{tabular}

The sea voyage in 1836

Document 9: the Official document on February $12^{\text {th }}$ sixteenth year of Minh Menh reign (1836)

Origin: Ministry of Construction and Transportation

Imperial city: Commander Pham Huu Nhat (marker planting); chose Ô ship to go to Quang Ngai, (Imperial guards surveyed and drew maps [ 5 , volume 4, 867]) Province: employed 4 ships from residents, sailors (labourers), boatmen

Commission

The sea voyage in 1837

Document 10: The Official document of July $11^{\text {th }}$ in the eighteenth year of Minh Menh reign (1837)

Origin: Ministry of Finance

Archive: National Archives Center

Imperial city: commander - Pham Van Bien, one of 2 Imperial guards was Truong Viet Soai (drew map), 22 soldiers 20 Admirals.

Province: 2 guides were Vu Van Hung and Pham van Senh, 31 sailors (labourer), 2 boatmen Nguyen Van Chom and Tran Van Duc, hired two big ships in Quang Ngai and two big ships in Binh Dinh

(Requested for allowance to provide rice for seamen who travelled to Paracel Islands. ) 


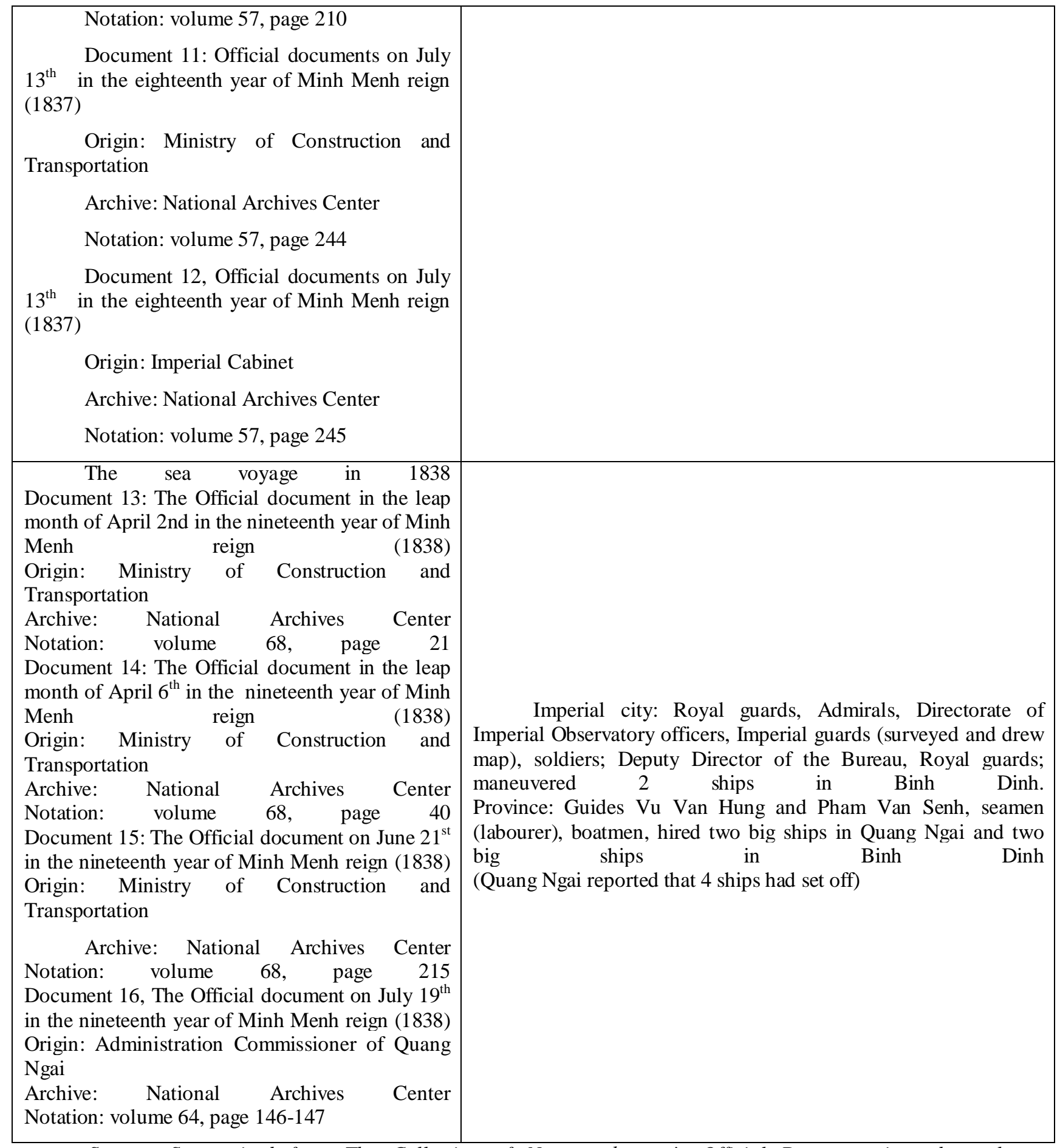

Source: Summarised from The Collection of Nguyen dynasty's Official Documentation about the implementation of Vietnam's sovereignty over Paracel Islands and Truong Sa archipelagos, supplemented from the "Dai Nam thuc luc" and "Kham Dinh Dai Nam hoi dien su le" (The author still remains the order as in the Collection).

- The sea voyages mentioned above indicate the following contents:

- Every year / annually / continuously for 6 years, King Minh Menh sent troops to Paracel Islands to explore, manage, and patrol the sea and island regions through various activities, such as: map drawing, border marker planting, temple building, tree planting, collecting commodities and rare seafood .

- The 1st, 3rd and 5th sea voyages only had information about the returning trip, the 2nd and 4th sea voyages only had information about the departing trip; only the 6th sea voyage had the information of both trips.

- By studying these 12 documents, in combination with "Dai Nam thuc luc" and "Kham Dinh Dai Nam hoi dien su le" and other researches, the participants and tasks of the fleet, selected by the King and provinces, were elucidated. 
- The task of each infantry office and the main mission would be different each year, depends on the King's order.

\section{About the participants in the fleets.}

\subsection{The imperial force}

The imperial force consisted of the Navy, labour soldiers, supervisors, guards, Directorate of Imperial Observatory, the Minister of Construction and Transportation and royal guards. This force received the order in the third week of January [7,183]. They would travel on 03 large ships from Thuan An estuary to Quang Ngai province and coordinated with the Quang Ngai's and Binh Dinh's forces.

\subsubsection{The Naval force}

Under King Minh Menh, the Navy was divided into 2 ranks: the central (Imperial city) and the local (or provincial). The central (Imperial city) was called the Imperial city Admiral. This naval force was fully equipped with weapons and ships as well as regular training to satisfy military and civilian requirements. Not every province had its own navy force. The number of troops in each province was not the same.

Recruited into the navy often were the people who lived in coastal areas. Sometimes, in order to get enough soldiers, the Court had to manoeuver troops from other units. The task of the Navy, ordered in the 14th year of Minh Menh (1833), was: "Practice continuously in training camps, fight vigorously in battles ..." [1.40]. The training regime of the navy was relatively strict with the exact requirements of the time. They not only practiced shooting guns with standing ammunition but also practiced with moving targets or used cannons to attack fake ships. The navy was trained to be familiar with sea ways, river ways, as well as hollow/deep/dangerous/safe topographics, small islands, big islands to avoid dangers. [review for additional references]

The main weapons of the Navy were guns, cannons and rifles, along with bullets, long spears, iron bars, firearms, fire hoses, long-handled sickles, stones, stone needles, all kinds of marine equipment in general. Besides the ships and essential armaments in the military, the Navy was also equipped with compassé, sandglassé, and Western telescopes. The King manoeuvered the elite naval force equipped with light and fast boats in order to chase down pirates in case of an encounter. In historical documentation of the Nguyen dynasty, pirates were commonly regarded as Chinese invaders, Te Ngoi invaders, Qing buccaneers, Do Ba invaders, Cha Va sea invaders, sea invaders, etc. In detail, in March 1985, corsairs robbed merchant ships in Sa Ky estuary of Quang Ngai. As a result, the naval forces also indirectly undertook additional tasks of besieging these pirates.

It can be inferred that there was a strong navy force under King Minh Menh which was trained and practiced all skills through military simulation and real battles. The Navy was equipped with guns, sandglasses, telescopes, and almost all naval weapons. The King used the naval troops in the Imperial City as an important core force to engage in sea voyages to Paracel Islands.[7,99/111/121/161]. Captains of the naval force in each year were Captain Truong Phuc Si (1833-1834), Captain Pham Van Nguyen (1835), Commander Pham Huu Nhat (1836) and Commander Pham Van Bien (1837). In addition, one important task of the Captain of the naval force is that once he reached an island; he had to pitch wooden stakes, which was prepared by the Ministry of Construction and Transportation as a border mark. On the wooden stakes marked the official year of the dynasty, the name of the state official and the powerful phrase of King Minh Menh which was "Obey the King's order"[7, 127]

\subsubsection{The Imperial guards}

The Nguyen dynasty had four parts of the Imperial troop; each team included 50 men. In 1833, the duty of the Troop was: as a part of the Department of Imperial Guards, the officers mastered the technique of hydrological measurements and Vauban Geometrical construction techniques, so they were sent to Paracel Islands to perform the tasks such as mapping, building shrines, building stone stelae, building fortifications and planting perennial trees. King Minh Menh was faithful in marine gods, so he ordered the erection of shrines and stelae to pray for a peaceful weather and the safety of sea voyages. [review for additional references: Phan Thanh Hai (2014), "King Minh Mang and a strategic vision of sea and islands displayed on The Nine Tripod Cauldrons of Nguyen Dynasty", Journal of Physical Cultural Heritage, vol.4 (49), page 38]

In each sea voyage from 1834 to 1838 , King Minh Menh assigned the mapping task to the Imperial guards. In particular, Captain Truong Phuc Si (1834), three Imperial guards Tran Van Van, Nguyen Van Diem and Nguyen Van Hoang (1835), Officer Truong Viet Soai (1837). However, after studying documents, I have not known the name of the officers who were assigned the task of surveying Paracel Islands in 1833, 1836 and 1838 yet.

Thus, the mission of the Imperial guards to Paracel Islands in each sea voyage was different, such as: surveying, map drawing; carrying materials to build the temple, stone stelae, building fortifications and planting trees. Perhaps, the most difficult task was measuring Paracel Islands. The results of the sea voyage in 1835, 1837, and 1838 showed that the map had not been completed; (the officers were) reprimanded by the King but were forgiven [7,111/121/145/175]. However, "The complete map of Dai Nam" ("Dai Nam nhat thong toan do"), drawn in 1838, was still the first administrative map of our country drawn in vertical manner, with the north on the top, the 
south on the bottom, the east on the right, and the west on the left (Harold, 2016). On this map, the image of Paracel Islands and "Van Ly Truong Sa" appeared on the right of the map, which is similar to later maps of Vietnam.

\subsubsection{Cong Tuong (Workmen)}

Repairing ships was assigned to workmen. They were divided into separate professions, set up teams to work at the governmental workshop. In addition, the workmen at the shipyards not only built new ships but also had to repair ships periodically. King Minh Menh always focused on repairing ships in the Imperial city and provinces before sending them out. He also ordered the workmen to bring materials along with them to repair the ships during the trip whenever needed. [7, 99]

\subsubsection{Directorate of Imperial Observatory}

Under King Minh Menh, he founded the Directorate of Imperial Observatory in every province to observe and forecast the local weather [5, volume 3,921], as well as recording irregular weather, then reported to him through a weather map which noted storms, droughts, floods in detail. Directorates understand astrology, the horizontal, longitude of the planet, the moon, the sun, the stars like Venus, Jupiter, Mercury, Mars, Saturn. They edited the "That Chinh" calendar and submit to the King.

In 1825, King Minh Menh gave the department three solar telescopes, astronomical telescope, and telescope. He said: "...Y You are the members of the Office of Imperial Observatory; the main task is to observe the sky and the earth. However, all of you have never used the provided telescopes, which is really lazy and irresponsible. The previous mistake can be forgiven. From this time, all of the members in this office have to take turn to learn how to use the telescopes, within 2 months all of you must use them well. Whoever disobeys this order is guilty. [5, volumes 5,824]

In August 1826, King Minh Menh gave the Department of Imperial Observatory two things - a barometer and a thermometer. The King had told the Ministry of Rites that: "The thermometer, when it is dry, its gas goes up and when it is wet, the gas goes down, using it to forecast weather is very precise. However, when the weather is warm but the gas goes down; when the weather is dull but the gas goes up, we can conclude that is irregular weather, which can make people get sick easily. Measuring the climate by this (tool) is a miracle. Knowing how to use it, (we) can predict the weather precisely" [5, volumes 2, 514]

In December 1838, King Minh Menh said that a marine worker must remember the sea routes, so he requested Ministry of Construction and Transportation to edit a book called "Hai trinh tap nghiem sach" (The collection of sea routes) based on researches of all related books. The book was divided into 4 sections with the following contents: 1 . General about wind and rain (meteorological and astronomical observation), 2. Taboos during the trip (abstinence and avoidance during the voyage); 3. Taboos in shipbuilding (abstinence and avoidance in shipbuilding), 4. Increase the experience (collection of experience in sea voyages). The content primarily focuses on assessing wind direction, so the boatmen can control the ship effectively. It is important that this book noted in detail damages occurred from 1820 to 1838 , which are the evidence for the theories mentioned in the book. [2, 35]. In addition, King Minh Menh requested the Ministry of Construction and Transportation to edit "Thuy su da cong khoa tich thuong phat le" - a training and test material for sailors. The journey diaries of the fleet, as well as the records from Department of Imperial Observatory, were helpful in the construction of these 2 books.

The king sent the Department of Imperial Observatory to participate in the sea voyage to Paracel Islands in 1838, they used the solar telescope, the astronomical telescope, along with the barometer, thermometer and astrological divination to record meteorology, hydrographic of the sea voyage. Therefore, everyone could minimize the risks and return safely. Through that we could see, King Minh Menh strongly believed in the ability of divination and the knowledge of astrology and geography of the Imperial Observatory Department [7,161].

\subsubsection{Deputy Director of the Bureau, Royal guards}

Through researching documents, I noticed that in 1838, the King sent Deputy Director of the Bureau Do Mau Thuong and the royal guard Le Trong Ba of the Ministry of Construction and Transportation to Paracel Islands, although it was not clear what their specific task was, but it is known that the guard was good at using telescope, so they can help inexperienced sailors to use this equipment.

\subsection{Provincial forces}

In the Sa Ky estuary, there were no rivers flowing out, so there was no alluvium accumulation, and its depth was relatively suitable for building a port. Both sides of the estuary were favorable for inhabitants, especially in the south, An Vinh commune (Ly Son Island, Vietnam), people lived by the seafaring and farming. The northern bank of An Hai commune was less prosperous and populated [8,47]. Re Islet is $27 \mathrm{~km}$ far from Sa Ky estuary and $50 \mathrm{~km}$ from Quang Ngai provincial capital, also known as Ly Son (is called isle Ré but according to the explanation of the folk is "island with many trees"). The Portuguese often called it Pulo Catah, the Chinese called it Ngoai La (Han Nguyen Nguyen Nha, 2018). In the early sixteenth centuries, there were seven fishermen in An Vinh village (An Vinh commune) in the mainland; they sailed to the west of the island and founded the An Vinh Ward. They were 
called "The Seven tribes" (Pham Van, Pham Quang, Vo Xuan, Vo Van, Le, Nguyen, Tran). Other 8 fishermen from An Hai village (An Hai commune) occupied the eastern part of the island and founded An Hai ward, they were called "The Eight Tribes" (Nguyen, Truong, Duong, Nguyen, Nguyen, Tran, Le, Vo). 2 seniors were dismissed, so currently, there were only 13 seniors on Ly Son Island.[6, 31]. That means, An Vinh ward and An Hai ward of the island were established by the original residents in An Vinh commune and An Hai commune on the mainland, which is Sa Ky estuary. On the island, the descendants were also fully responsible for their home village on the mainland. During sea voyages to Paracel Islands, they usually carried a pair of mats, seven rattan cords (or shrubs), seven bamboo braces. If, unfortunately, during the sea voyage, someone unluckily died, others would use the mats to wrap his body, tied with the bamboo braces and rattan cords and then dropped him into the sea. A small bamboo card with his name, place of birth and military unit was attached in the mats carefully as a note to anyone who fished the body would know who he was and that he had sacrificed for the country [6.68].

\subsubsection{Guides and boatmen}

King Minh Menh ordered to hire the ship, seamen, and boatmen through the Ministry of Construction and Transportation in order to prepare for the voyage to Paracel Islands [7,183]. The King ordered each province to recruit experienced seamen and sailors, especially those who had been to Paracel Islands. As for the position of steerer, the province would issue a license for the steerer [7, 99/145/153]. In 1835, in 1837, and in 1838, Vu Van Hung (or Vo Van Hung) and Pham Van Senh (or Pham Van Sanh) were all credited and assigned to lead the fleet to Paracel Islands. In 1834, Vu Van Hung was still the guide; however, there was no information about Pham Van Sang. Vu Van Hung was a member of the Vo family in An Vinh village, he was the descendant of Vo Van Khiet (the captain of Paracel Islands fleet in 1776), Vo Van Phu (the captain in 1803) [8, 95]. Vu Van Hung also assisted the province with the selection of boatmen: Dang Van Xa (An Hai Ward) (1834) Duong Van Dinh (Hoa Diem village) (1834) and Luu Duc Truc 1837). All these boatmen were licensed by the province.

\subsubsection{Sailors}

Fishermen (laborer, sailors) recruited to the fleet were called the militia [7,145/153/161/183]. They were not considered official military and were not paid monthly; however, they were untaxed and granted 1 or 2 quan (the unit of currency under the Nguyen dynasty) depending on the sea voyage [7,111/121/145/153]. In addition, they also got the remainder after repaying a required amount of money to the Court. They performed the imperial duty seriously and exactly (Pelley, 2011). Sailors joined the sea voyage in 1834 were the citizens of Ly Son Island. They were Pham Quang Thanh (Pham Quang Thanh or Pham Quang Tinh), Tran Van Kham and Vu Van Noi (Vo Van Cong) - An Vinh Ward; Nguyen Van Manh and Truong Van Tai - An Hai Ward. Besides, there were three other sailors in Quang Ngai province including Ao Van Tram - Le Thuy Dong Nhi Commune, Binh Ha canton, Binh Son District; Tran Van Le and Nguyen Van Doanh, all of them were all from Thach Than village, Ca Duc canton, Mo Hoa district [8.95 / 96], [7.99]. Boatmen selected by officers to Paracel Islands were untaxed in the same year. However, many people did not receive this special privilege, so the Administration Commissioner of Quang Ngai province reported clearly the main task of these ships was for surveying and drawing map in Paracel Islands to request the privilege $[7,183]$.

\subsubsection{Supplies}

The province provided rice and other necessary supplies for sailors, while other food such as fish, birds, etc. were self - supplied by hunting [7,137]. Each ship had a fire oven, which was the traditional type with coconut kindling.

\subsubsection{Ships}

Seamen's ships were built by themselves (look at the illustration of a ship in the seventeenth century below). It is a small ship or small fishing ship with bamboo bottom covered of buffalo excrement and dipterocarpus alatus (a tropical forest tree). The top of the ship was made of wood or starry wood, 3 masts made by oak trees. All the latches were made by poon trees; this kind of trees was popular in the local. Compared with ships made in other locations, ships in Sa Ky estuary or Ly Son Island had three sails woven by leaves, water jars were made of bamboo. Therefore, the seamen's ships were both small and light and could reach the shore of Paracel Islands easily [6.70 / 71]. Paracel IslandsParacel IslandsIn 1838, Quang Ngai province hired two large ships. The first ship belonged to Nguyen Van Cho, ship number 22, 2.70m in lengths, $6.7 \mathrm{~m}$ in width, $2.1 \mathrm{~m}$ in depth. The second ship belonged to Tran Van Duc, ship number $89,9.5 \mathrm{~m}$ in length, $6.7 \mathrm{~m}$ in width, $2.3 \mathrm{~m}$ in depth $[7,183]$. Therefore, two boatmen Nguyen Van Cho and Tran Van Duc also joined to the voyage in 1837. 


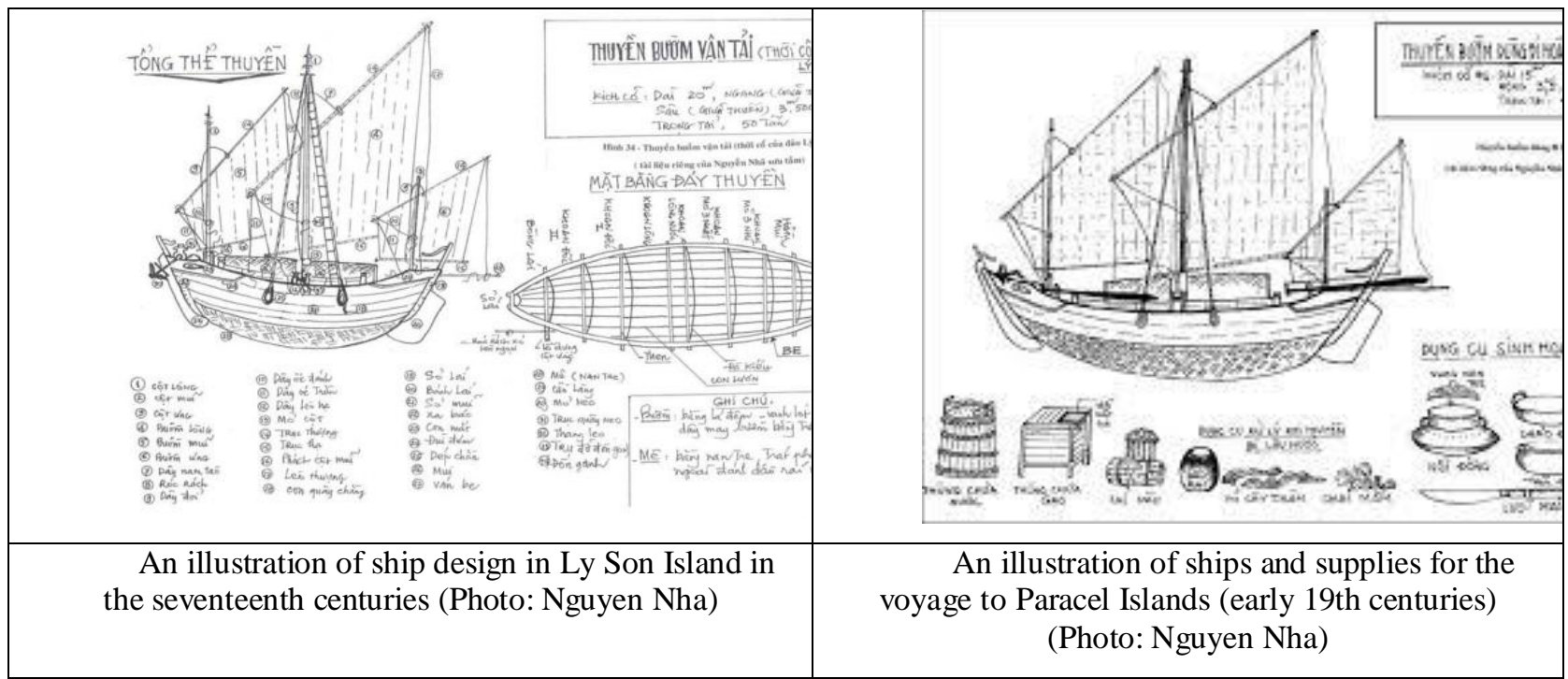

\section{Activities of the forces participating in the voyage}

Each year, in the East Sea, the were 9 - 10 storm on average; these storms usually had a passing line or swept through the waters of Paracel Islands archipelago. Typhoons caused heavy rain, high waves, strong winds, and many difficulties construction process and facilities in the archipelago. In the summer, the south-west wave directions were dominant with $53-55 \%$, the wave height was $3-4 \mathrm{~m}$. The other wave directions were of low frequency and the height was less than $3-4 \mathrm{~m}$. In the winter, the North - East waves were dominant with the frequency of $70-72 \%$ and the maximum height of $4-6 \mathrm{~m}$. The East and North waves had the frequency of 10-15\% and the maximum height of 3-4m (Han Nguyen Nguyen Nha, 2018). As a result, in the winter, the coastal areas of Quang Tri to Quang Ngai often received damaged vessels floating from Paracel Islands. This showed that Paracel Islands team went to Paracel Islands in the third week of March and back to the mainland at the time of June was a reasonable schedule, however, there were cases when the time was postponed.

The departure time for the annual survey, if postponed due to the weather, would be reported to the King [7,161]. The plan was usually in the third week of March [7.99/161/183]. To wish for a safe voyage to Paracel Islands, in the $15^{\text {th }}$ year of Minh Menh (1834), King requested Quang Ngai province to pray for the wind [7.99]. A ceremony at the estuary was not only to satisfy the spiritual need of the court and the soldiers but also to appease and reassure the families of the soldiers who died on the journey; at the same time, it also encouraged them to actively engage in the dangerous sea voyage, help them avoid being disappointed and hesitated when they faced hardship. This was also a chance for King Minh Menh to show his care to the fleets and stabilize the willingness of the members.

Naval officers and envoys of the Imperial city started from the Thuan An Gate to Quang Ngai province and then coordinated with the militia of Quang Ngai province or joined with the supplement militia of Binh Dinh. If the delay was reasonable, there would be no punishment, however, if it was due to neglect, the fleet would be heavily punished.[7,161].

From Sa Ky estuary, the fleets, included the royal ship, the ships of Quang Ngai province or the ships of the citizens in Binh Dinh province, took 3 days 3 nights to go to Paracel Islands [7,167], [6,78], [6,39].

After arriving to Paracel Islands, each member had their own duty. When they had free time, all of them would collect exotic species such as sea holothurian, snail, cochlea, which were as big as a mat and contained pearls as big as a child's finger. Their color may not as beautiful as mussel pearls; however, the shell could be separated into pieces or used as decoration; there were a very large tortoiseshell, the sea monster, or "white cotton". Besides sea product, they also collected goods from wrecked ships such as gold, silver, guns, bronze, tin, black lead, ivory, beeswax and porcelain. Collecting guns was probably the most important task because it could improve the military strength of the court (Han Nguyen Nguyen Nha, 2018).

After finishing the task assigned by the king, the fleet returned to the mainland following the planned schedule in the third week of June [7,161 / 183], crossing Thuan An estuary and then headed to the Imperial city to report the situation of the sea voyage. At the same time, they must submit all of the productions they got on that sea voyage. If someone tried to hide anything for himself, the Ministry of Construction and Transportation and Ministry of Justice would directly investigate him [7,111]. When they arrived at Thuan An estuary, if Tran Hai fortress hung a red flag to congratulate and shot the canon, the fleet would be announced that the waves might be vigorous, so they should delay the landing. Once the wave became peaceful, they would hear 3 big shots. As the navy troops were always on the voyage, the fleet would always hang a yellow flag and shoot canon once they landed. At night, 
the flag was replaced by a large lantern, seven or eight meters in circumference, wrapped in white paper, covered in fabric. In rainy and windy months, the fortress did not hang lanterns. The meaning of flag and canon shooting in transfering information was mastered thoroughly by the Navy under King Minh Menh [4, 589-590].

On the other hand, drawing the map of Paracel Islands was probably the most difficult task, therefore until 1838 the map of Paracel Islands had not been completed yet. In addition, repairing broken ships was equally important; therefore, the fact that the king requested all workmen to join in the sea voyage was necessary. In the sixth journey in 1838, the king sent officers of Imperial Observatory and the Ministry of Construction and Transportation (a Vice minister and the royal guards) to Paracel Islands. Officials of Imperial Observatory were highly skilled in divination and good at astrology and geography, so their task recording the meteorological and hydrographic states during the voyage to Paracel Islands, which helped the fleet greatly reduce risks and return safely. Guards and Officials of Imperial Observatory were also good at using the telescope.

\section{Conclusion}

Through 6 sea voyages to Paracel Islands, it is clear that the implementation of sovereignty over Paracel Islands in the Nguyen dynasty was continuous and uninterrupted from 1833 to 1838, which was the continuity of a process established by the Nguyen Lords from hundreds of years ago. Participants of the fleet to Paracel Islands included the imperial army and local people in the estuaries of Sa Ky and Re Islet (Ly Son island) in Quang Ngai province, in addition, there were many seamen and boatmen of Binh Dinh province. It was the responsibility of the entire Nguyen dynasty government system, from the central to the local level and of all relevant components.

The main force sent by the imperial court to Paracel Islands was the elite naval force - they were trained to assess all required skills through military stimulation. Besides the naval force, the Imperial guards were an indispensable force in every sea voyage. In each sea voyage, they had different tasks such as measuring and mapping; bringing materials to build the temple, building steles, construction and planting trees.

The second component of the fleet was the seamen, who knew the sea and had experience of traveling to Paracel Islands. They were selected to be guides and steerers; they were also the descendants of the members in previous fleets to Paracel Islands. Particularly for the position of steerers, each candidate must apply to the province, if the province approved, they would receive a license. If necessary, the court would also select the boatmen from residents who lived in the coastal area of Binh Dinh.

Before each sea voyage, King Minh Menh prepared the fleet carefully, from training skills for the fleet's members to recruiting experienced candidates. The King also prepared supplies to prevent ship damages during the voyage. He also paid attention in motivating each member of the fleet by performing a ceremony before their departure.

The activities during this period under King Minh Menh clearly showed the strict management ability of the Court, the responsibility of the national leader to the national territory in general and islands in particular. The indisputable sovereignty in Paracel Islands from 1833 to 1838 , which was the continuity of a process established by the Nguyen Lords from hundreds of years ago, left many valuable experiences and was a strong foundation for the development and protection of sea and island sovereignty until today.

\section{ACKNOWLEDGEMENTS}

This research is funded by Vietnam National University HoChiMinh City (VNU-HCM) under grant number B2017-18b-01

\section{REFERENCE MATERIAL}

[1]. Bui Gia Khanh (2013) Navy force of Nguyen dynasty in Gia Long and Minh Menh reign. Journal of Historical Research ISSN 0866 -7497, No 7 (447), 38-50

[2]. Dinh Thi Hai Duong (2014) Security policy - coastal defense of Nguyen dynasty in the first half of the nineteenth century (1802-1858). Journal of Historical Research ISSN 0866 -7497, No 11 (463), 26-38

[3]. Harold E. Meinhiet, "Unveiling Vietnam: The Maps of Alexandre de Rhodes" (The Portolan, Spring 2006); Harold E. Meinhiet, "The Bishop's Map: Vietnamese and Western Cartography Converge" (The Portolan , Winter 2016), 28-40.

[4]Han Nguyen Nguyen Nha (2018), Vietnam, Territoriality and the South China Sea Paracel and Spratly Islands (2018), Routledge, 190 page

[5]. Nguyen Thi Thu Thuy and Nguyen Phuong Nga (2016), Navy force of Nguyen dynasty under Gia Long and Minh Menh reign. Vietnam Social Science ISSN: 1013-4238, No 10 (107), 46-56.

[6]. Imperial Cabinet of Nguyen dynasty (1973), "Kham dinh Dai nam Hoi dien su le", volume 5 Thuan Hoa - Hue Publishing House. 
[7]. Keyuan, Z. (2001). Historic rights in international law and in China's practice. Ocean Development \& International Law, 32(2), 149-168.

[8]. McGarry, B. (2018). Third Parties and Insular Features After the South China Sea Arbitration. In Chinese (Taiwan) Yearbook of International Law and Affairs, Volume 35 (2017) (pp. 99-135). Brill Nijhoff.

[9]. National history of the Nguyen Dynasty (2007), "Dai Nam thuc luc" , volumes 2/3/4/5, Educational Publishing House, Ha Noi

[10]. Tran Nam Tien (2014), Paracel Islands teams in the history of protecting the sovereignty of the sea island of Vietnam, Culture and Arts Publishing House, Ho Chi Minh city.

[11]. The national boundary commission (2013), Collection of Official documents of Nguyen dynasty about enforcing Vietnam's sovereignty over Paracel Islands and Spratly Islands, Knowledge Publishing House, Hà Nội.

[12]. Quang Ngai Department of Culture, Sports and Tourism (2013), Quang Ngai island: historical economic - cultural, Labor Publishing House.

[13]. Pelley, P. (2011). Vietnamese Historical Writing. na.

[14]. Ramsay, J. (2008). Mandarins and Martyrs: The Church and the Nguyen Dynasty in Early NineteenthCentury Vietnam. Stanford University Press.

[15]. Tran Duc Anh Son (2014), Documentation of Vietnam's sovereignty over the Paracel Islands archipelago, Culture and Arts Publishing House.

[16]. Van-Loi, Luu (1995), Vietnam - China Dispute over the Paracels and Spratlys, The People's Police Publishing House

[17]. Vo Long Te cited from M.A. Dubois de Jancigny và Jean Baptiste Chaigneau. See: Vo Long Te (1974), Op.cit. p.168.).

[18]. <http://www.gazeta.ru/ science/2014/06/01_a_6054413.shtml>, Вьетнамцы никогда не смирятся. газета.ru, accessed February 12, 2018.

[19]. Vu Quang Viet (2010), Op.cit

[20]. $<$ https://leminhkhai.wordpress.com/2013/08/24/the-dai-nam-nhat-thong-toan-do-and-the-mapping-ofthe-mekong, accessed February 13, 2019>, accessed February 02, 2019

[21].<http://www.vusta.vn/en/news/Potential-partnerships/Evidences-to-affirm-Paracels-Islands-underVietnam-s-sovereignty-44867.html>, accessed February 01, 2019

[22]. < http://www.mowcaparchives.org/items/show/95>, "Imperial Records Of Nguyen Dynasty (18021945)," MOWCAP ARCHIVE, accessed February 13, 2019, 